others. Will we not, therefore, have to cut down very materially the great length of time generally believed to have elapsed in this region from the beginning of this lacustrine period to the present time, when we find that a great portion of the sediment that once filled the lakes is due, not to the products of erosion, as has hitherto been supposed, but to repeated showers of volcanic dust? Again, do not these volcanic materials, which must have fallen in showers over a large extent of country,-accumulating in some cases in beds forty to ninety feet thick, -account for the perfect preservation of the vertebrate remains which characterize the formations in so many parts of the west; and is there not also suggested one possible cause for the extinction of some of the many groups of animals which have at present no descendants in this region, and whose only remains are the bony fragments found in these lacustrine deposits?

U. S. geological survey.

A. C. Peale.

Carnivorous prairie dogs.-Carnivorous orioles.

The statement of $R$. W. Shufeldt that his pair of young prairie dogs took kindly to a meat diet (Science, viii. p. 102) attracted my attention and interest, for it recalled to my mind an experience of my own in the summer of 1838 . Having a pair of the marmots at this moment under observation here, $\mathrm{I}$ determined to try them with a piece of raw beef, and the eagerness with which they plunged at it (for their avidity cannot be characterized by any milder word) was certainly something very astonishing. Their ordinary vegetable food they take quietly, but the beef stemed to set them frantic. They acted as though they were famishing, - they seized it so fiercely, figbting with one another for it, and hastening back to ask for more. And so it has continued. Their owner fears to feed them with it exclusively, but gives them more or less daily, and the contrast between their eagerness for the meat and their quiet consumption of vegetables is a very instructive lesson. Their stomachs, out on the plains, always hold vegetable contents and nothing else. This was doubtless the first piece of meat ever tasted by either of these. Whence this craving appetite?

The experience of 1838 to which I referred was this: That was in the earlier days of my 'natural history,' three years before my first ichthyological paper was written. I had taken three young Baltimore orioles from their nest, but feared that I should lose them, for they refused every variety of food I offered them. At that time I was collecting birds zealously, and was skinning several of them daily. As I was preparing a specimen, one of the young orioles was sitting on my table, very stupid indeed, head drawn in, not life enough to utter a sound, thoroughly dumpish. Without knowing why, I picked up a bit of the bird's flesh and offered it to him. To my great surprise he swallowed it on the instant, and roused himself at once. That one mouthful had done him so much good that he wanted more. I took him on my finger and fed him piece after piece, till his throat was swelled out like an over fed chicken's crop, and I feared to give him more. He settled himself down with great satisfaction, and went to sleep. I fed his brother and sister in the same way; and from that time till they were fully grown they had not a mouthful of food except the flesh of the birds I was skinning. Their eagerness for the meat was extreme. They learned the bird-skinning business to perfection. As soon as they saw me prepared for work, they all gathered about the specimen, ravenous for meat, and I almost always commenced to skin my bird, with an oriole sitting on each hand, and one on the specimen itself, and with three little heads down over the abdomen, where the first cut was to be made (they knew the point well enough); and the instant I opened the skin, in went three bills, digging and tearing fiercely for their food, and continuing at it as I continued: my work, till their appetites were satisfied.

$I$ do not know that this fact concerning the Baltimore oriole has ever been reported. I recollect mentioning it to $\mathrm{Mr}$. Audubon, but it was after his account of the species had been published.

New London, Conn., Aug. 11.

W. O. Ayres.

\section{Flooding the Sahara.}

In our own country an evaporation of two feet per year is a small figure, and twice that amount has been recorded in some cases; so that it would seem to be safe to assume that it would exceed the latter value in the north of Africa. Taking Mr. LeConte's figures (Science, vol. viii. p. 35), and an evaporation of two feet per year, and the cubic feet evaporated, on an area of 3,100 square miles would be $2 \times 864$. $230 \times 10^{5}$ cubic feet $=1,728,460 \times 10^{5}$ cubic feet per year. But the inflow, according to his assumptions, would be $1,262,277 \times 10^{5}$ cubic feet per year; so that at the rate of $t w o$ feet of evaporation per year, the amount evaporated would be 1.3 times the amount of the inflow. In other words, at the rate of inflow assumed, the depression to be flooded would never be so far filled as to make a surface of 3,100 square miles : and if the evaporation be four feet per year, the inflow would necessarily be nearly three times. that assumed by Mr. LeConte.

Hoboken, Aug. 14

De Volson Wood.

\section{Barometer exposure.}

The discussions in Science relating to the effect of high winds upon the indications of a barometer in a room, have been bighly interesting. I only desire at this time to present a few facts that bear upon the problem, and to correct a few misconceptions. No one that has attempted making a fire in a very cold room, on a very windy day, with a refractory chimney in the fore ground, can be easily convinced that there is much of a draft up a cold chimney, even with a hurricane. Even if there were such draft, the air must flow in through all the cracks, especially on the wind ward side, and equilibrium would thus be kept up. It should be noted also that the wind does not blow steadily, but rather in gusts ; consequently there can be no such thing as a permanent lower pressure inside than outside a room, but a momentary depression by a gust would be relieved almost immediately by the lull.

This is shown beautifully by a barograph properly arranged. All references will be to a barograph inclosed in a tight glass case, such as has been adopted by Mr. Hough of Albany. The fluctuations are so rapid that they cannot be seen on a sheet carried at the rate of one to two inches per day, but only upon 